\title{
Case Study of Patients with HIV during the COVID-19 Pandemic
}

\section{Maria Olalla Garcia* (D), Franklin Escobar Lumitaxi and Miryan Guambuguete Llumitaxi}

Nursing Career, Faculty of Health and Human Sciences, Bolivar State University, Academic Campus

"Alpachaca", Av. Ernesto Che Guevara s/n and Av. Gabriel Secaira, Guaranda, Ecuador.

\begin{abstract}
HIV patients are a vulnerable population to COVID-19, being an infectious disease, even sharing drugs for its treatment. At present, this population has been affected in its care, personal and social dimensions. The COVID-19 health crisis has impacted the regular surveillance and medical supplies needed to keep the deadly disease under control. The objective was: To relate the experiences of patients with HIV who are treated at the Leon Becerra Camacho Hospital of the canton Milagro (Ecuador), during the COVID-19 pandemic. The case study follows the qualitative methodology with a phenomenological approach, with a population of 10 patients diagnosed with HIV who are treated at the Leon Becerra Camacho Hospital. The qualitative data collected was analyzed using the Atlas ti V.9 software. It was known that patients with HIV felt affected at the care level because they did not receive periodic control, likewise anxiety and fear of a possible contagion has generated preventive isolation as a self-care measure. Regarding the information needs, the reports indicated that there is a lack of knowledge in aspects related to the preventive biosafety measures applicable to patients with HIV. In conclusion, there is a significant difference in the quality of care offered to patients before the pandemic and during the pandemic.
\end{abstract}

Keywords: HIV, COVID-19, treatments, stories, experiences

*Correspondence: molalla@ueb.edu.ec

(Received: June 23, 2021; accepted: December 14, 2021)

Citation: Garcia MO, Lumitaxi FE, Llumitaxi MG. Case Study of Patients with HIV during the COVID-19 Pandemic. J Pure App/ Microbiol. 2022;16(1):3-9. doi: 10.22207/JPAM.16.1.20

(C) The Author(s) 2022. Open Access. This article is distributed under the terms of the Creative Commons Attribution 4.0 International License which permits unrestricted use, sharing, distribution, and reproduction in any medium, provided you give appropriate credit to the original author(s) and the source, provide a link to the Creative Commons license, and indicate if changes were made. 


\section{INTRODUCTION}

Patients with HIV are vulnerable to infectious diseases, including COVID-19. The pandemic has affected this population in various ways, from care, personal, and social perspectives. The COVID-19 health crisis has impacted the regular surveillance and medical supplies needed to keep HIV under control. To convey the experiences of patients with HIV during the COVID-19 pandemic, this case study combined qualitative methodology with a phenomenological approach to evaluate a population of 10 patients diagnosed with HIV who were treated at the Leon Becerra Camacho Hospital of the canton Milagro (Ecuador). Qualitative data were analyzed using Atlas.ti v.9. At the level of care, patients with HIV did not receive periodic preventive care. Likewise, anxiety and fear of infection prompted preventive isolation as a selfcare measure. Regarding information needs, there was a lack of knowledge related to preventive biosafety measures applicable to patients with HIV. These findings reveal that there is a significant difference in the quality of care offered to patients before and during the pandemic.

A new infectious disease, the Coronavirus 2019 (COVID-19), has emerged and spread throughout the world, wreaking havoc on a health and social level. Despite significant recent research, COVID-19 shows high rates of infection and mortality. This crisis has affected the health sector. Patients with frequent, chronic or incurable diseases have been affected by social distancing measures or lack of medications because these were used to treat patients with COVID-19.

This case study was aimed at understanding the stories and experiences of patients with human immunodeficiency virus (HIV) during the current global pandemic of COVID-19 caused by severe acute respiratory syndrome virus 2 (SARS-Cov2).

As indicated by the World Health Organization, ${ }^{1}$ people with HIV, a chronic disease directly related to the immune system, are among the most vulnerable populations to SARS-Cov2, which causes COVID-19. The disease is considered highly serious and can be fatal, especially for individuals with pathologies related to the respiratory tract or immune deficiencies, such as HIV.
Although there are no solid data for the combined prevalence and relationship between COVID-19 and HIV, the pandemic has had a clear impact at the healthcare level. In light of the demand for antiretrovirals used to treat both diseases, the WHO has warned of the possibility that the inventories available to patients with HIV will decrease, putting treatment at risk.

The prevalence of HIV was investigated in the province of Guayas, where this case study was carried out. According to data extracted from the Yearbook of Health Statistics: Beds and Hospital Discharges for 2019, in Guayas, a total of 1.518 admissions for HIV were reported, of which 49 patients were treated in the canton Milagro, Ecuador. Although exact statistics for the current population treated at the Leon Becerra Hospital are not managed, it is vitally important to understand the issues faced by this vulnerable population, as they are marginalized by the monopolization of local health systems due to the rapid spread of the pandemic in the town.

\section{MATERIALS AND METHODS}

For the phenomenological analysis, 10 patients diagnosed with HIV who were treated at the Leon Becerra Camacho Hospital were included. The sampling strategy was non-probabilistic and voluntary. For convenience, patients who wished to participate voluntarily in the case study were selected

Study information was collected through in-depth interviews according to Ander-Egg. ${ }^{2}$ This is an important approach in qualitative research that can be open or semi-structured. The type of interview must generate appropriate information for determining if the experience it relates had central or peripheral significance. Personal context must be expressed in idiosyncratic beliefs, ideas, and associations. The interviews were carried out after obtaining written informed consent from each patient certifying the ability to use the information provided via written and audio routes.

The qualitative data were analyzed using the Atlas.ti v. 9. In brief, a hermeneutical unit was generated using codes, citations, and analysis networks to facilitate the interpretation of the information contained in each interview. 
The objects used were as follows: 10 DPs, 10 transcribed interviews (DPs); 4 codes, analysis categories; 10 Memos, subcategories; 10 citations, Information on importance coded according to the aims of the study.

\section{RESULTS}

Based on the purpose of the research, the following categories and subcategories were established.

\section{DISCUSSION}

\section{Care before the pandemic}

An important aspect of this study was to understand the experiences of the patient population with HIV in terms of care before and during the pandemic. Based on interviews, it was clear that before the pandemic, the care and attention received was more personal and detailed, with "slower" care, as described by some. During the health crisis due to the pandemic, health personnel focused on the control and care of patients with COVID-19. This account of care before the pandemic was given by patients who were up to 19 years of age treatment for HIV.

These findings are consistent with the level of care received by patients in different locations, both in Ecuador and worldwide, as described by Mejía et $\mathrm{al}^{3}$ who indicated that "during the contingency due to COVID-19, some

\section{Time of diagnosis}

\section{Attention and care}

\section{Habits and customs}

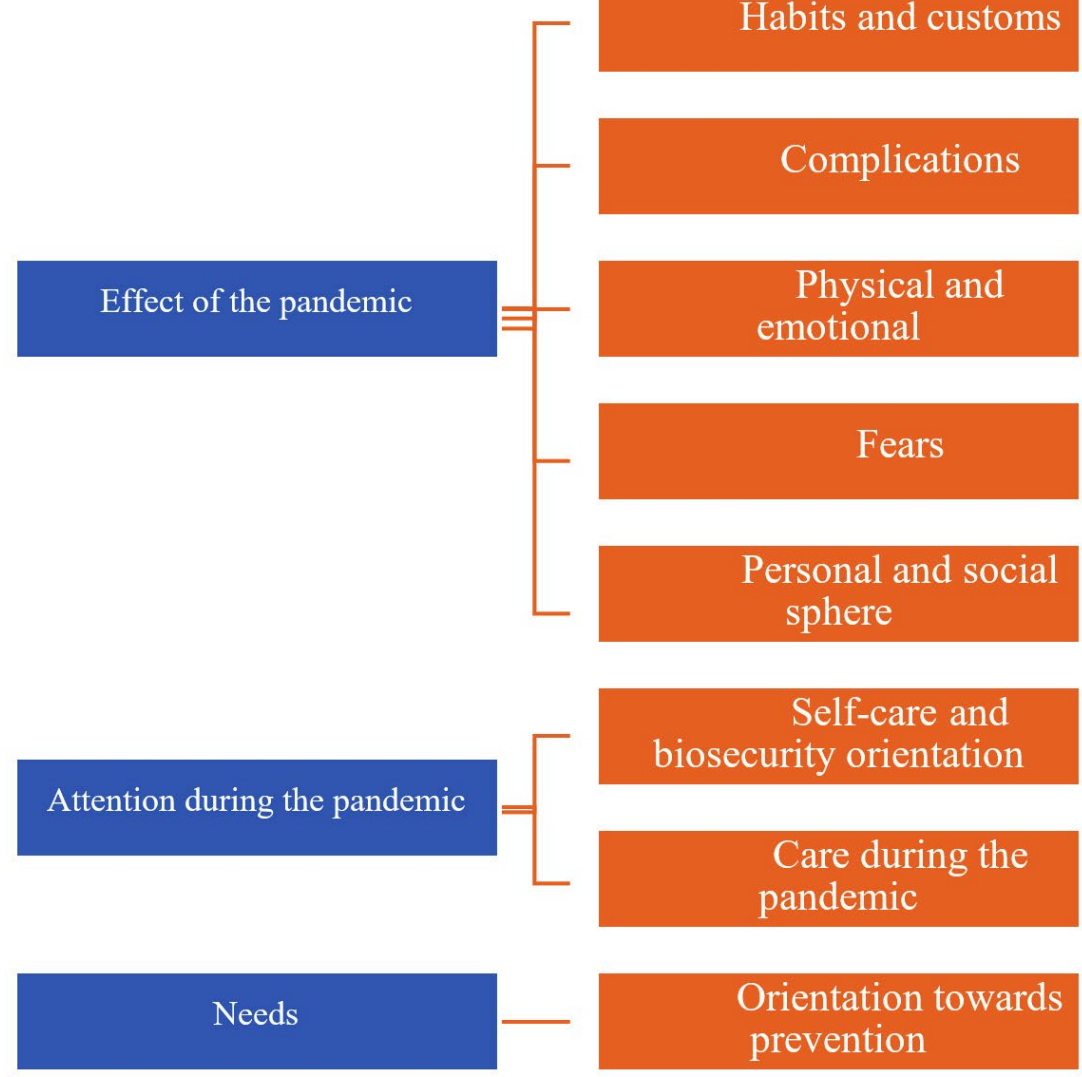

Fig. 1. Analysis categories and subcategories. 
Table 1. Category 1, Pre-pandemic care

\begin{tabular}{|c|c|}
\hline Category & Subcategories \\
\hline $\begin{array}{l}\text { Category } 1 \\
\text { Pre-pandemic care } \\
\text { "The attention was not particularly good and it is still } \\
\text { bad, since doctors and nurses are worried about the } \\
\text { virus and do not pay much attention to us, despite } \\
\text { feeling very bad." (Patient interviewed)"Let's see, } \\
\text { before the COVID-19 pandemic, the care was good. } \\
\text { There is a slight difference during the pandemic. } \\
\text { However, before the pandemic, care was sometimes } \\
\text { excellent and sometimes not. With this pandemic, } \\
\text { care has been slower due to all of the cases because } \\
\text { we know that the pandemic at the national level } \\
\text { affects different hospitals and cases are not } \\
\text { concentrated in one area." (Patient interviewed) }\end{array}$ & $\begin{array}{l}\text { Time of diagnosis patients with VIH } \\
\text { "It has been } 2 \text { years since I found out that I had this } \\
\text { disease." (Patient interviewed) } \\
\text { "Approximately } 5 \text { years." (Patient interviewed) } \\
\text { "Three weeks ago." (Patient interviewed) } \\
\text { "Ten years." (Patient interviewed) } \\
\text { "Since } 2002-19 \text { years ago." (Patient interviewed) } \\
\text { "Two years ago, when I was pregnant with my daughter, } \\
\text { at } 6 \text { months of pregnancy." (Patient interviewed) } \\
\text { Attention and care } \\
\text { "In the hospital, good care was provided before the } \\
\text { pandemic, with good treatment of the nursing staff." } \\
\text { (Patient interviewed) } \\
\text { "Well, very good because I was able to attend my } \\
\text { appointments on time." (Patient interviewed) }\end{array}$ \\
\hline
\end{tabular}

of the hospitals that provide care for PLHIV have been converted to COVID-19 care centers and there is the possibility that medical care may be affected." These contingencies have impaired access to quality control and care for patients with HIV, affecting compliance with treatment and increasing the already persistent emotional burden, as these individuals feel excluded by society.

\section{Effect of the pandemic}

The pandemic has had a plausible impact at the level of healthcare in general. The rapid increase in patients with COVID-19 with different symptomatological profiles and different degrees of complications has led to the hoarding of services, who substantial effort aimed at containing the progression of the disease and restoring the health of the majority of affected patients.

However, despite the priority of care for this emerging group of patients, there are various vulnerable groups with high incidence rates of infectious diseases in the population over several decades. Among these groups, patients with HIV were the focus of this case study.

Regarding the social and family environment, patients included in the study indicated that their daily tasks were affected by new social dynamics, distancing measures, and fear of contracting the disease, and these effects even extended to work-related activities due to the need to avoid contact with other individuals and to reduce levels of exposure.

On the other hand, the interviewees indicated that the effects of the pandemic included difficulties in going to hospital appointments, withdrawing from medications required for their treatment, and quality of life issues.

In this sense, Blanco ${ }^{4}$ explains that since the beginning of the COVID-19 pandemic, people with HIV have been included as one of the highest risk groups due to their immune deficiencies, highlighting that the pandemic is generating an adverse effect on the mobility of patients, access to controls, and medication, leading to a change in the paradigms for monitoring this group by health systems.

In the personal sphere, the effects of the COVID-19 pandemic described by patients with HIV who participated in the study included limitations related to socialization; as explained by some subjects, outings are restricted to the hospital, for truly necessary matters.

In terms of physical and emotional factors, fears experienced during the pandemic included unmet needs and the inability to access medications in a timely manner, with health consequences due to the discontinuity of treatment.

According to Guo et $\mathrm{al}^{5}$ this fear is presented in a general way, since patients are aware that the treatment of COVID-19 involves 
Table 2. Category 2, Effect of the pandemic

\begin{tabular}{|c|c|}
\hline Category & Subcategories \\
\hline $\begin{array}{l}\text { Category } 2 \\
\text { Effect of the pandemic } \\
\text { "Yes, because we avoid going out and participating in } \\
\text { family gatherings, which makes us feel bad." (Patient } \\
\text { interviewed) } \\
\text { "Well, since I was not prepared for this, the truth is } \\
\text { that it affected me psychologically. I felt quite bad, } \\
\text { worried that I might not receive good treatment, } \\
\text { but I have been able to adjust." (Patient interviewed) } \\
\text { "Actually, the greatest fear that is not my own but is } \\
\text { shared by everyone, is contracting the disease; } \\
\text { avoiding infection is what one has to prioritize. We } \\
\text { have to avoid infection, even when others take } \\
\text { preventive measures, and we have quarantined as } \\
\text { appropriate. That has been the greatest fear." } \\
\text { (Patient interviewed) } \\
\text { "My fears, more than anything, is the knowledge that } \\
\text { this disease is contagious, it causes death, and it } \\
\text { occurs more in individuals with illness or extreme } \\
\text { anxiety." (Interviewed patient) }\end{array}$ & $\begin{array}{l}\text { Habits and customs } \\
\text { "My daily work has been affected." (Patient interviewed)" } \\
\text { "Of course, it is regenerating anxiety, isolation."(Patient } \\
\text { interviewed) } \\
\text { "Yes. Well, in the little that one has been able to survive, } \\
\text { have any business or any sale, one has no longer been } \\
\text { able to go out and do things, the jobs that used to be } \\
\text { done this way." (Patient interviewed) } \\
\text { Complications } \\
\text { "Actually, I have not had any major complications, I have } \\
\text { been taken all the preventive measures that I have been } \\
\text { able to, I have taken all of my medications, I have not had } \\
\text { any complications; so, let's say that I have taken care to } \\
\text { the greatest possible extent." (Patient interviewed) } \\
\text { Physical and emotional } \\
\text { "Well, yes, because when we were in quarantine and } \\
\text { under curfew, when we went to an appointment we } \\
\text { had to queue and the curfew time would arrive and it } \\
\text { would be postponed to another day." (Patient interviewed) } \\
\text { Fears } \\
\text { "To become infected myself or to infect my relatives, my } \\
\text { children." (Patient interviewed) } \\
\text { "Get infected and have contact with someone who has } \\
\text { covID-19 who can infect me, my mother, or my family." } \\
\text { (Patient interviewed) } \\
\text { Personal and social } \\
\text { "Well, the social: there are almost no meetings, as you } \\
\text { are aware that this is contagious. Now, socializing is } \\
\text { restricted." (Patient interviewed) } \\
\text { "Not so much because I have always spent more time at } \\
\text { home for my business, but everything changed with this } \\
\text { pandemic. Now we only go to the hospital and from } \\
\text { there to home. We can no longer be calm on the street; } \\
\text { I am very afraid." (Patient interviewed) }\end{array}$ \\
\hline
\end{tabular}

Table 3. Category 3, Attention during the pandemic

\begin{tabular}{ll}
\hline Category & Subcategories \\
\hline $\begin{array}{l}\text { Category } 3 \\
\text { "Before the pandemic, it was better; now, because of } \\
\text { these diseases, nothing is the same." }\end{array}$ & $\begin{array}{l}\text { Attention during the pandemic } \\
\text { Self-care and biosecurity orientation } \\
\text { "Yes, I have received talks in the hospital from health } \\
\text { professionals. I have also investigated things that I }\end{array}$ \\
$\begin{array}{l}\text { "Well, not all care, but in areas where they have been } \\
\text { able to do the most, I am sure they have helped me. } \\
\text { I have done my part to the best of my ability, that is, } \\
\text { I have tried to help myself so that the situation is not } \\
\text { too complicated, but they have shown their expertise } \\
\text { and knowledge." (Patient interviewed) }\end{array}$ & $\begin{array}{l}\text { alcohol." (Interviewed patient) } \\
\text { Care during the pandemic }\end{array}$ \\
"Regarding nursing care, yes, but at the social level, \\
there are many people who still refuse people who \\
have this disease." (Patient interviewed)
\end{tabular}


Table 4. Category 4, Needs

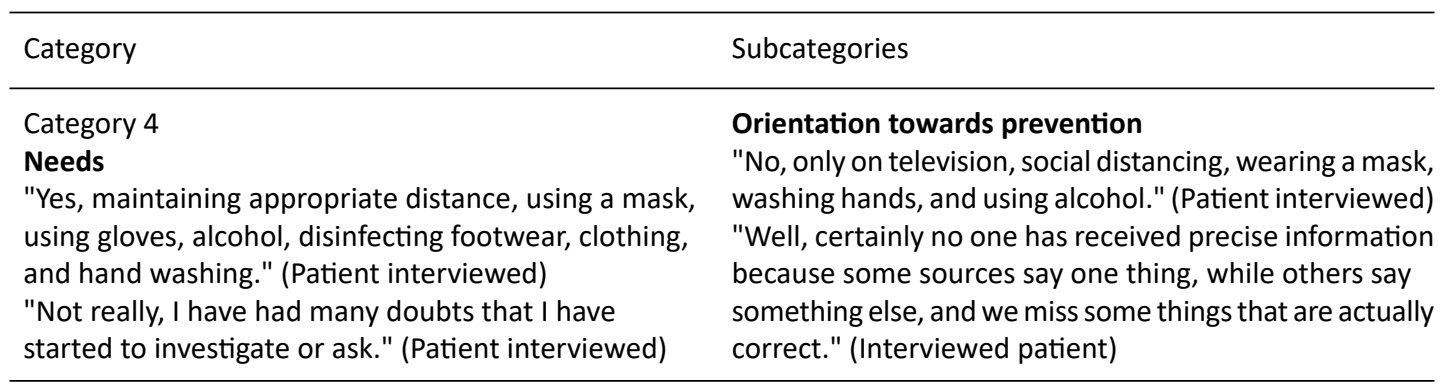

some drugs used for the treatment of HIV and therefore fear that these are in short supply and access to them is difficult.

Furthermore, the main fear was becoming infected or infecting relatives. As a population with a previously acquired disease and an understanding of its complications, being in contact with other individuals with the potential to spread COVID-19 causes anxiety and stress.

This is explained by Ballester \& $\mathrm{Gil}^{6}$ who highlighted that this group of individuals has experienced high levels of fear, anxiety, and stress due to the possibility of catching the new virus, particularly due to the general ignorance of the population about COVID-19 and its spread. The study also highlighted that one of the greatest concerns in the population is the potential for the pandemic to have a negative effect on access to treatment, as a result of the overcrowding of health centers and the risk of going to pharmacies to obtain antiretroviral drugs.

\section{Attention during the pandemic}

As in previous sections, this study evaluated aspects directly related to care during the pandemic in order to determine the general effect of the health crisis on patients with HIV and to determine if patients were provided pertinent information regarding biosafety and self-care.

In this regard, patients explained that although the care received has not been optimal during the pandemic, health professionals have tried to provide the best possible care in the face of many limitations. For example, with regard to orientation towards self-care and biosecurity, some patients indicated that they received consultations and talks about the prevention of COVID-19.
Posada et $\mathrm{al}^{7}$ explained that the high number of people who require stricter periodic face-to-face control, due to the low level of virological control in different countries, as well as the restrictions of health personnel with respect to mobility, trying to maintain greater social isolation, necessitates the analysis of new care alternatives that promote adequate follow-up, timely delivery of the treatment, prevention of interruptions, and reduction of the risk of contracting COVID-19.

Needs

In some cases, patients indicated that they had not received detailed information oriented towards the prevention of the disease. Accordingly, when they had doubts, they investigated issues on their own and thus applied the corresponding preventive measures.

An important intervention revealed that despite current knowledge of HIV, at the social level, the stigma associated with this population persists by denying infected individuals, an aspect that has been accentuated by the presence of this new infectious disease of COVID-19.

As asserted by the Joint United Nations Program on HIV/AIDS (UNAIDS), the stigma of populations during a pandemic can exacerbate and increase violence, isolation, and the harassment of infected individuals with HIV, thus increasing pre-existing inequalities UNAIDS. ${ }^{8}$

\section{CONCLUSIONS}

This case study revealed that there is a significant difference in the quality of care offered to patients with HIV before and during the COVID-19 pandemic, with a constant deterioration in access to consultations, access to medicines, the timing of treatment, and individualized attention. 
In the context of the pandemic, patients with HIV have experienced greater levels of isolation to reduce exposure to the virus, directly affecting the ability to visit the hospital for any activity related to treatment and control as well as social and work-related activities.

Regarding the physical and emotional needs of the population, timely access to treatments and routine medical appointments is a priority. Likewise, the accounts of patients with HIV showed that during the pandemic, there was substantial fear and stress related to the possibility of becoming infected or infecting relatives.

According to the reports of patients with HIV, a lack of information about COVID-19 and preventive measures from health professionals led individuals to seek out required information from various sources. It is important to highlight that among the 10 patients included in the study, none reported COVID-19 during the investigation.

\section{ACKNOWLEDGMENTS}

The authors would like to express their sincere gratitude to Professor Dr. Favian BayasMorejon for the advice in the development of this work, also to the State University of Bolivar and the staff of the Luis Becerra Camacho Hospital for all the support received.

\section{CONFLICT OF INTEREST}

The authors declare that there is no conflict of interest.

\section{AUTHORS' CONTRIBUTION}

$\mathrm{FE}, \mathrm{MG}$ and $\mathrm{MO}$ wrote the manuscript. FE and MG collected information and surveyed hospital staff. MO interpreted the data obtained and designed the tables. FE and MO supervised the manuscript. MG drafted and approved the final manuscript for publication.

\section{FUNDING}

None.

\section{DATA AVAILABILITY}

All datasets generated or analyzed during this study are included in the manuscript.

\section{ETHICS STATEMENT}

This article does not contain any studies with human participants or animals performed by any of the authors.

\section{REFERENCES}

1. World Health Organization. Questions and answers about COVID-19, HIV and antiretrovirals 2020. https:// www.who.int/es/news-room/q-a-detail/coronavirusdisease-covid-19-hiv-and-antiretrovirals.

2. Ander-Egg E. Learn to investigate. Basic notions for social research (1 ed.). Brujas. 2011 https:// abacoenred.com/wp-content/uploads/2017/05/ Aprender-a-investigar-nociones-basicas-Ander-EggEzequiel-2011.pdf

3. Mejía J. Considerations for the care of people living with HIV in the context of COVID-19. National Institute of Medical Sciences and Nutrition "Salvador Zubirán". 2020. https://www.incmnsz.mx/2020/ CONSIDERACIONES-CLINICAS-COVID19-VIH.pdf. Accessed date: 12/09/2021

4. Blanco J. COVID-19 in people living with HIV. Revista Enfermedades Emergentes, 2020; 19 (3): 189-190. http://www.enfermedadesemergentes.com/articulos/ a759/taller_TBC2020_mesa_2.pdf Accessed date: $02 / 11 / 2021$

5. Guo W, Weng HL, Bai H, et al. Rapid Community Survey on the Impact of the COVID-19 Outbreak on the Health Care of People Living with HIV. Zhonghua Liu Xing Bing Xue Za Zhi. 2020;41(5): 662-666. doi:10.3760 / cma.j.cn112338-20200314-00345

6. Ballester R, Gil M. The virus that changed Spain: impact of COVID 19 on people with HIV. AIDS Behav. 2020;24: 2253-2257. doi: 10.1007/s10461-020-02877-3

7. Posada M, Alzate J, Martínez E. COVID-19 and HIV. Colombia Médica, 2020; 51 (2): 1-10. http://www. scielo.org.co/pdf/cm/v51n2/es_1657-9534-cm-5102-e4327.pdf Accessed date: 02/11/2021

8. UNAIDS. Address stigma and discrimination in responding to COVID-19. Geneva: ONUSIDA 2020. Retrieved on December 16, 2020, de http://onusidalac. org/1/images/covid19-stigma-brief_es.pdf Accessed date: $12 / 12 / 2021$ 